Journal of Social Science 3(4): 213-222, 2007

ISSN 1549-3652

(C) 2007 Science Publications

\title{
Human Resource Development Strategies: The Malaysian Scenario
}

\author{
Haslinda Abdullah, Raduan Che Rose and Naresh Kumar \\ Graduate School of Management, Universiti Putra Malaysia, Malaysia
}

\begin{abstract}
The socio-economic development of Malaysia is greatly influenced by human resources activities in both the private and public sectors. But the private sector, particularly the industrial sector is the key player for the country's economic growth. In acknowledging human resources importance in this sector, the country's developmental plans developed thrusts that support the development of human resources to become skilled, creative and innovative. This article examines the concepts and nature of human resource development (HRD) at the national level in Malaysia. In examining HRD from the national perspective, a review of documentary evidence from relevant Governmental reports and documents was utilised. The plans, policies, strategies, roles and responsibilities in HRD at the national level were discussed.
\end{abstract}

Key words: Human resource development; national HRD; Malaysia

\section{INTRODUCTION}

Malaysia gained its independence in 1957 and during this period, the economic activities of the country depended on commodities such as rubber and tin in which it soared the economic growth of the country. Being a country having various races and ethnic groups and most of the native bumiputra living below poverty triggered a racial antagonism in 1969 . The Government then structured a policy to reduce and eradicate poverty and to reduce social disparities in which the plan covered a span of twenty years beginning from 1970 to 1990 . And during this period, the economic of the country showed a steady growth from being an agriculture-based economy in 1970s to industrial-based economy in 1980s. With the economic activity influenced by industrialisation, the Government realised that human resources in the industrial sector are the major driving factor for the country's social and economic growth. Hence, the Government began planning a strategy to develop human resources to support the country's socio-economic activities. Thus this article aims to examine and highlight Malaysia's HRD plans, policies and strategies in her move to develop human resources to sustain economic growth and compete in the global market. The country's development plans and policies as well as the economic development which lead towards the country's plans for a knowledge-based economy with knowledge-based workforce were studied and reported.

\section{MATERIALS AND METHOD}

A review of Governmental statistics, reports and other documents such as from the Ministry of Human Resources, Ministry of Finance, Department of Statistics, Ministry of International Development Authority, Prime Minister's Department and the Ministry of Education. In addition, conversations with officers in the Ministry of Human Resources formed the basis for data and information gathering.

Development Plans: Malaysia began formal planning for development in 1950 with the publication of the Draft Development Plan of Malaya. There are two types of development planning document to date. There are one twenty-year and two ten-year outline prospective plans and eleven five-year development plans including the Draft Development Plan of Malaya which was for six-year duration ${ }^{[1]}$. The five-year plans incorporate the strategies, programmes and projects designed to achieve the objectives of the long-term strategic plans. All the long term strategic objectives of the long term plans are essentially the same, that is to achieve rapid economic growth and attained significant improvements in its socio-economy, especially in alleviating poverty and society restructuring. And these long term plans are designed to achieve the objectives of the country towards becoming a united and fully developed nation status in the year 2020 under the country's 'Vision 2020'.

Corresponding Author: $\quad$ Dr. Haslinda Abdullah, Graduate School of Management, Universiti Putra Malaysia, Fax: +60-603-8943-4019 
Table 1: Development Planning Document

\begin{tabular}{lc}
\hline \multicolumn{1}{c}{ Plan Title } & Duration \\
Draft Development Plan of Malaya* & $1950-1955$ \\
General Plan of Development & $1956-1960$ \\
Second Five Year Plan & $1961-1965$ \\
First Malaysia Plan & $1966-1970$ \\
OPP1** & $1971-1990$ \\
Second Malaysia Plan & $1971-1975$ \\
Third Malaysia Plan & $1976-1980$ \\
Fourth Malaysia Plan & $1981-1985$ \\
Fifth Malaysia Plan & $1985-1990$ \\
OPP2*** & $1991-2000$ \\
Sixth Malaysia Plan & $1991-1995$ \\
Seventh Malaysia Plan & $1996-2000$ \\
OPP3*** & $2001-2010$ \\
Eight Malaysia Plan & $2001-2005$ \\
Ninth Malaysia Plan & $2006-2010$ \\
Source: Economic Planning Unit & \\
$*$ Six-year duration & \\
$\quad * *$ Twenty-year Outline Prospective Plan & \\
$\quad * *$ Ten-year Outline Prospective Plan \\
$\quad$ The objective of Vision 2020 to reach the standard
\end{tabular}

The objective of Vision 2020 to reach the standard of living of industrialised countries by the year 2020, have been clearly communicated and disseminated to all the organizations and its employees. The specific objective of the plan is to accelerate industrial restructuring, technological upgrading, human resource development and industrial linking. Malaysia's Eighth Development Plan emphasises on shifting the growth strategy from input-driven to knowledge-driven in order to enhance potential output growth to accelerate structural transformation within the manufacturing and services sectors and to strengthen socio-economic stability. The plan also focuses on providing initiatives to the private sector with the public providing the institutional framework and quality service. Special emphasis is given on increasing productivity and efficiency through HRD, encouraging research and development activities as well as utilizing the latest technologies, particularly the use of information communication technologies (ICT) ${ }^{[2]}$. And the latest Ninth Malaysia Plan has placed investments in human capital as the main thrust as its strategy. The aim of the 9MP is develop an efficient and talented workforce to increase overall national productivity and growth. In addition, incentives and support towards the private sector to increase productivity, enhance human capital and technology development continues from the $8 \mathrm{MP}^{[3]}$.

Economic Development: From independence in 1957 to 1971 , the economy of Malaysia was previously subjugated by commodities such as rubber and tin. The export of these primary commodities contributed to the steady economic growth of the country. Being a country having multi-cultural and multi-ethnic groups, the Bumiputra forms the largest groups, and around half of the Bumiputra households are living below the poverty line. The economic and social disparities fuelled racial antagonism and misunderstanding occurs. The ethnic riots in 1969 led to a review in the national development policy. A structured episodic plan known as the First Outline Prospective Plan (OPP1) was introduced, covering a span of twenty years from 1971 to 1990. The OPP1 was formulated to form as a substructure for policies and strategies formulation for the New Economic Policy (NEP).

The NEP has two goals, first, is to reduce and eradicate poverty and secondly, to reduce and eradicate identification of economic function with race. In particular, the NEP is implemented to reduce the economic and social disparities of the indigenous Malays. The NEP induced a dramatic increase in governmental intervention in the Malaysian business and society. Under the NEP, employment and business quotas for Bumiputras increased considerably.

With the implementation of the NEP, the Malaysian economy showed a dramatic growth. From 1971 to 1990 , the country's annual average growth in GNP was 6.8 per cent with the major export of palm oil, timber, rubber tin and oil. With the Prime Ministership of Tun Dr Mahathir in 1981, the NEP saw the creation of significant increase in bumiputra commercial, industrial and professional communities. The NEP saw the Government encouraging the growth of private enterprises and incentives such as investments credits, tax exemptions and credit subsidies were provided to develop export manufacturing and the Government began emphasising development in the manufacturing sector. Hence, the development of free industrial zones (FIZ) attracted foreign direct investments (FDI) particularly in the electronics and electrical industries. By late 1980s, manufacturing dominated Malaysia's export. Major exports included electrical and electronic products, chemicals, processed foods, textiles and processed timber and rubber products.

At the same time, steel, automobile and heavy industries were also established. Heavy Industries Corporation of Malaysia (HICOM) was set up to encourage industrial diversification, generate modern manufacturing activities, and fostering upstream industrial activities. With the support and incentives from the Government, was able to set several automobile companies. One such company is Proton, Perodua and Modenas, the national car project.

In June 1991, the Second Outline Perspective Plan (OPP2) was established. OPP2 is the first phase of the nation's journey to realise the country's Vision 2020 to achieve a developed nation status. The OPP2 provided 
the platform for the implementation of the New Development Policy (NDP) upon expiration of NEP in 1991. The NDP still retained the broad goals of NEP but it also focus on hardcore poverty, emphasise on the rapid development of an active Bumiputra Commercial and Industrial Community (BCIC), greater reliance on the private sector to achieve the restructuring objective and the strengthening of human resources development $^{[4]}$.

Rapid growth through the mid 1990s saw the expansion of share in the economy of the Bumiputra population without reducing the economic attainment of other groups. Despite the financial crisis in October 1997 to 1998, the high growth rate was maintained with low inflation, full employment and price stability. As United States is the main trading partner for electrical and electronics products, the Government pegged the exchange rate of Malaysian Ringgit to US dollar to maintain the Malaysian Ringgit.

In addition, the large inflow of the foreign direct investment (FDI) into the manufacturing sector added capacity to the export-oriented industries. This includes the oil, gas and petrochemical sector and investments in capital-intensive and high technology areas, all of which attracts and influences the high rate in private investment. At the same time, the inflow of FDI was not affected by the economic crisis as the reinvestments were stabilised by the established MNCs. The major portion of the FDI inflows are mainly in the high technology areas and the information technology (IT) sector. As such, the country saw a steady growth in the Gross Domestic Product (GDP) for 1999 as 6.4 percent and increased to 8.4 percent in $2000^{[5]}$.

The shift from an input-driven strategy to a productivity-driven strategy during the OPP2 period was affected by the economic crisis in 1997. However, the OPP2 saw success in achieving its goals with strong fundamental despite this crisis and enabled the country to recover and grow at an annual average rate of 7 percent per annum from 1991 to 2000 . The growth was based on input-driven, particularly from capital as the Total Factor Productivity (TFP) was 28.4 percent of GDP growth, the contribution of labour was 25.9 percent and that of capital was 50.2 percent. During the $1996-1997$ period, exports grew by 7.3 percent per annum but subsequently slowed down to 0.5 percent in 1998 due to economic contraction but a higher export growth of 14.1 percent per annum was achieved during the 1999-2000 period largely due to the growth in world demand for electronic products and the recovery of the regional economies. And also, during the 19982000 period, the government adopted additional measures to increase productivity, which included the allocation of more resources for research and development (R\&D), expansion of education and training and technology improvements.

OPP3 is the second phase in achieving the Vision 2020 objective. And under the OPP3, the National Vision Policy (NVP) forms the basis of the strategies and programmes under the OPP3. The objectives of the NVP are to develop Malaysia into a knowledge-based society; generating endogenously-driven growth through strengthening domestic investment and developing national capabilities, while continuing to attract FDI in strategic areas; increasing the dynamism of agriculture, manufacturing and services sectors through greater infusion of knowledge; addressing poverty and equity ownership of Bumiputras in business sectors; and finally, reorientating human resource development to support knowledge-based society ${ }^{[6]}$.

Under the ongoing OPP3, in 2001, the GDP grew an anemic 0.5 percent due to global uncertainties but a better expansion was seen in 2002 with 4.1 percent increase in the GDP and subsequently rises to 5.3 in 2003. The positive expansion was due to the growth in the manufacturing sector particularly in the electronics and chemical industries, coupled with the increase in FDI and tax exemption. The implementation of the Asean Free Trade Area (AFTA) in 2003 also helps in thrusting the economic expansion. Hence, the economy continues to grow by an approximate of 7.6 percent in 2004. In addition, this is due to the strengthening of macroeconomic fundamentals and the financial sector together with the strong performance of the economy during the OPP3 period, particularly in $2000^{[5]}$.

With the maturing economy, there is less reliance on labour and capital input as a source for growth as TFP contributed 37.2 percent, while the contribution of labour is 21.5 percent and capital contribution is 41.3 percent. The increase in TFP contributes to the growth in the structural transformation in upgrading economic efficiency. This includes emphasis on improving skills and management capabilities, increasing R\&D spending and greater use of technology and information technology (IT) in all economic sectors, in line with efforts to develop the knowledge based economy. In addition, the government increases public investment to improve the education and training delivery system.

Developing Malaysia into a Knowledge-Based Economy: In tandem with the objective of OPP3 to achieve the nation's Vision 2020, the development of the country into a knowledge-based economy (k- 
economy) is rapidly progressing. The concept of keconomy is the generation and utilization of knowledge in contributing towards the economic growth and creating the nation's wealth. Knowledge is currently the key driving factor for growth strategy other than labour, capital, raw material and entrepreneurship in production.

The notion of knowledge-based economy is ability of the human capital to create, innovate, generate and exploit new ideas as well as apply technology and exercise superior entrepreneurial skills. Organizations are to become more knowledge-intensive when more industries are adopting the concept of knowledge-based workforce. Accordingly, the economy will be characterised by knowledge-based activities and hightechnology industries accounting for a significant share of employment, GDP and exports. Hence, knowledge will become a commodity to be traded, besides being a factor of production.

The government have started implementing several initiatives to facilitate the smooth development of $\mathrm{k}$ economy, particularly in the areas of HRD, science and technology (S\&T), research and development, infostructure and financing. Examples of some of these initiatives include the launching of the National IT Agenda (NITA) and the Multimedia Super Corridor (MSC). These initiatives is to position itself in the global-map of knowledge-based economies and to undertake measures in ensuring that equitable access is targeted to all segments of Malaysia society. As a whole, k-economy provides the means to maintain sustainable rapid economic growth and competitiveness in the medium and long term. As mentioned earlier, the private sector will continue to become the engine of growth in k-economy with support from the public sector. At the same time, the objective of social and economic equity will still be a critical element in this new stage of economic development but with the added responsibility of narrowing the knowledge gap among various groups, between urban and rural communities and across the regions. Hence, having the national policies and plans in place to drive human resources, private and public sector to achieve k-economy, who is responsible for coordinating and administration of the plans, policies and strategies implemented? Therefore, the role and responsibility of Ministry of Human Resources is vital to be discussed.

Human Resources Administrative System: The administrative system of HRD in Malaysia is governed by the Ministry of Human Resources. The objective of the Ministry is to develop a competitive workforce of industrial harmony and social justice. This objective is keeping with Government's policy under NVP. As in table 1, there are several departments, statutory bodies, company and Advisory Council under the Ministry of Human Resources headed by the Minister of Human Resources. There are nine departments, two statutory, one company and four Advisory Councils. These authorities are responsible for a whole range of activities related to human resources. For instance, Human Resources Development Council is involved in the development and upgrading the skills of workers in the manufacturing and services sector. And the National Vocational Training Council is involved with the development, training and education of human resources in specialised technical skills ${ }^{[5]}$. Broadly, the departments, statutory bodies, company and advisory councils that falls under the hierarchy of the Ministry of Human Resources, governs the country's employment systems and functions such as recruitment, selection, industrial and employment relations, training and development and also the safety and health of human resources in the working environment.

In addition to the governing authorities and bodies under the Ministry of Human Resources, other Ministries are also part of the system in the development of human resources. For instance, the Ministry of Education, Ministry of Entrepreneurship and Ministry of Youth and Sports, and Ministry of Higher Education. These ministries play a major role in supporting the development of human resources in Malaysia by providing the human capital with preemployment knowledge and skills required by industries.

HRD Policies and Legislation: The Government's plans of developing the economy based on knowledgeable workforce are clearly apparent under the National Vision Policy (NVP). Out of seven critical thrusts in the NVP, two thrusts specifically relates to HRD: 1) developing a knowledge-based economy as a strategic move to raise the value-added of all economic sectors and optimizing the brain power of the nation; and 2) strengthen human resource development to produce a competent, productive and knowledgeable workforce 
Fig. 1: Human Resources and HRD Administrative System

\begin{tabular}{llll}
\multicolumn{1}{c}{ Department } & \multicolumn{2}{c}{ Ministry of Human Resources } & \\
\hline Fig. Statutory Bodies & Company & Advisory Council \\
\hline - Manpower Department & - Social Security & $\bullet$ National Institute of & $\bullet$ National Labour Advisory \\
- Labour Department (P. Malaysia) & Organisation & Occupational Safety & Council \\
- Labour Department (Sabah) & (SOCSO) & and Health & - National Council for \\
- Industrial Court & - Human Resources & & Occupational Safety and Health \\
- Industrial Relations Department & Development & - National Vocational Training \\
- Trade Union Affairs Department & Council & Council \\
- Occupational Safety and Heath Department & & Wages Council \\
- National Vocational Training Council & &
\end{tabular}

Source: Ministry of Human Resource

Department, Statutory Bodies, Company and Advisory Council in bold are directly involved in HRD

Moreover, besides the thrusts under the NVP, the Ministry of Human Resources have its own policy to support the thrusts. The human resources development policy under the Ministry of Human Resources focuses on supporting organizations to attain improvement in worker productivity, efficiency, value-added operations and competitiveness both domestically and globally ${ }^{[2]}$.

The Government under Ministry of Human Resources have implemented the Human Resources Act in 1992 to support the Government's plans and policies for human resources development. This Act is empowered to impose and collect human resources levy from employers to promote employees training and development. The Act is implemented to pool all levy collected from employers to establish a Human Resources Development Fund (HRD Fund). In addition, the establishment of the Pembangunan Sumber Manusia Berhad (PSMB) (Human Resources Development Council) to administer the HRD Fund is one of the priority and purpose of the $\mathrm{Act}^{[2]}$.

\section{Statutory Bodies}

HRD Council: the objective of PSMB is the imposition and collection of human resources development levy for the purpose of promoting employees' training and the establishment and administration of the HRD Fund. The main function of the PSMB is managing the HRD Fund through designing the terms and conditions under which any financial assistance or other benefits are given. The PSMB is also responsible to assess and determine the types and extent of employees' training and retraining in keeping with human resources needs in the industries.

National Vocational Training Council: The National Vocational Training Council (NVTC) or locally known as Majlis Latihan Vokasional Kebangsaan (MLVK) was established under the Ministry of Human Resources on 2 May, 1989. The purpose of the Council is to promote and coordinate skills training strategy and programmes to support Malaysia's technological and economic development needs. MLVK is primarily concerned with establishing a coordinated skills training system in line with Malaysia's goals and needs; promoting the development of skills training and certifying skills competence.

In establishing a coordinated skills training systems, currently four main Ministries have been given the responsibility in carrying out the pre-employment skills training, i.e. Ministry of Human Resources through the Manpower Department, the Ministry of Education through its Technical Education Department, The Ministry of Entrepreneur Development and Ministry of Youth and Sports. On the other end, in the private sector, pre-employment skills training is carried out by the many training providers which covers a wide-ranging of courses and qualifications.

In promoting the development of skills training, it is the responsibility of the MLVK to promote and coordinate the skills training. Both the public and private sectors have a vibrant partnership in ensuring that MLVK is attuned to the needs of the industry. And at the same time, in setting standards for a skilled workforce, MLVK seeks to ensure that skills training programmes are benchmarked against actual workplace requirements, as required in the competency-based training approach. This benchmarking is by developing the National Occupational Skills Standard (NOSS). By utilising NOSS as the basis for delivering training programmes, training providers can ensure that their trainees meet the workplace competency requirements expected by Malaysian Industries. This is because training providers or institutions can be given accreditation under the National Skills Certification 
System if the training programmes provided are of NOSS quality.

\section{Financial Support}

HRD Funds: The Human Resources Development Act, 1992 as detailed above provides for the establishment of Human Resources Development Fund (HRD Fund). This fund was implemented in January 1993 and acts as a central pool of funds that make up Human Resources Development Levies collected from all employers. Under the Act, each and every employer is liable to pay Human Resources Development levy in respect of every employee at the rate of one percent of the monthly wages of the employee. For smaller industries with not more than 49 employees and a paid-up capital of less than RM2.5 million is given the option to a levy at 0.5 percent and the remaining is subsidised by the Council. This incentive is to support the smaller industries in ensuring that employees are given the training needed.

The objective of having the HRD Fund is to provide financial assistance to defray part of the training costs for all retraining and skills upgrading programmes undertaken by employers. It is not a subsidy scheme but rather a cost-sharing effort between employers and the HRD Council. By establishing the HRDF, it is the Government's initiative to encourage the employers in the manufacturing and services sector to retrain and upgrade the skills of the employees in consonance with the needs of the business and industrialisation strategy of the country.

The funds are used for promoting, developing and upgrading of employees, inclusive of provision of training facilities. It is also used as financial assistance to employers by way of grants or loans for the purpose of employees' training. The financial assistance provided also includes subsidising the costs incurred by employers in the training or retraining of employees. Other than working employees, the funds are also available for assisting the retrenched workers in terms of training and skills upgrading.

Skills Development Funds: The Government emphasis on skills training is apparent from early 1990s, from the Sixth Malaysia Plan (6MP) right to the current Ninth Malaysia Plan (9MP). During the 6MP, RM612.2 million was allocated for skills training alone and this has increased during Seventh Malaysia Plan to RM1.662 billion and the Eighth Malaysia Plan, the allocation for training is RM4 billion ${ }^{[8]}$. The Skills Development Fund Division (SDF) is responsible for the administration of funds for skills training under the Ministry of Human Resources.

\section{Education and Training}

Higher Education: The Malaysian Government is also emphasising on higher education in nurturing a knowledgeable and skilled workforce. This is clearly seen in the development of a variety of institutions from universities, university colleges, polytechnics, community colleges, training colleges and colleges. These institutions allow for numerous options for higher education in the professional, semi-professional or specific skills areas ${ }^{[9]}$.

As mentioned earlier, in keeping with achieving the knowledge-based workforce, the level of education of the workers is very important. The workers are encouraged to have tertiary university education or at least technical and vocational education. The numerous institutions established in Malaysia support theses options by providing a variety of information technology (IT) and information and communication technology (ICT) related, engineering, and business related courses in the certificate, diploma and degree level.

In addition, there is a popular demand for a professional distinction of MBA level of education in the industries in which these courses are available in all these institutions. It is known that MBA level of education have workers who understand the fundamental of the business concept and strategies and they are seen to be very relevant in the current globally competitive business environment.

Technical Education and Vocational Training: Other than tertiary university education, a polytechnic system of education has been set up by the Ministry of Education to meet the growing demand for skilled manpower. As of end 2003, there are 16 polytechnics all over the country which operate under the Ministry of Education, offering technical and vocational education. These polytechnics are managed by the Ministry of Technical Education Department (Jabatan Pendidikan Teknikal) (JPT).

The role of JPT is to conceptualise the policy and direction of technical and vocational education development to comply with the needs of industrial and national development. JPT also ensure that technical and vocational education are successfully implemented and coordinated, as well as designing, developing and evaluating the effectiveness of technical and vocational education curriculum. All the programmes offered at 
the polytechnics for school-leavers are full-time at certificate and diploma levels. The duration for certificate courses is two years and three years for the diploma courses. However, there are part-time programmes for working individuals who were former polytechnic graduates.

These polytechnics offered a very high level of education and training in science and technology. The courses offered covered a range of technical specialities, for example, electrical and electronics engineering, mechanical engineering, civil engineering, building services engineering, IT, food technology, architecture, and others. Other than technical specialities, the polytechnics also offered programmes on business related such as banking, accountancy, hospitality management and fashion designing. Currently, these institutions are also offering courses on English language.

Training Schemes: Up to mid 2004, there are 18 training schemes available under the HRD Council. These schemes ranges from the main funding scheme, consultancy services, computer and ICT related, apprenticeships, scheme for retrenched workers and the unemployed, and graduate training scheme. The list of schemes is as below:

- The SBL (Skim Bantuan Latihan) Scheme

- The PROLUS (Programme Latihan yang diluluskan) Scheme

- The PLT (Pelan Latihan Tahunan) Scheme

- Juruplan Scheme (Consultancy Scheme for Training Needs Analysis)

- SMI Training Needs Analysis Consultancy Scheme

- The PERLA (Perjanjian Latihan dengan Penyedia Latihan) Scheme

- The Apprenticeship Scheme

- SBL Pre-Approved Scheme (Skim Bantuan Latihan Pra Kelulusan)

- SBL-KHAS Scheme

- Group Training Scheme

- Joint Training Scheme

- Purchase of Training Equipment and Provision of Training Room

- Purchase of Personal Computers

- Computer-Based Training (CBT) Scheme

- Retrenched Workers and Unemployment Training Scheme

- Workers' ICT Training Scheme

- Information Technology \& Computer-Based Training Scheme

- Graduate Training Scheme
The main funding scheme called The SBL Scheme (Skim Bantuan Latihan) (translated meaning Training Support Scheme) is a scheme in which employers can freely decide the types of programmes for skills training and skills upgrading to be provided to the employees and claiming financial assistance towards the provision of the training programmes. However, this scheme needs prior approval before claims can be made. Another scheme, in which no prior approval is needed, The PROLUS (Program Latihan Yang Diluluskan) scheme enables employers to make claims for training provision for programmes provided by Approved Training Providers (ATP).

Employers are also provided assistance in terms of training needs analysis, systematically formulation of training programmes and annual plans. These schemes are: The PLT (Pelan Latihan Tahunan) Scheme, Juruplan Scheme (Consultancy Scheme for Training Needs Analysis) and SMI Training Needs Analysis Consultancy Scheme. The PLT Scheme is only a one off exercise to assist employers. The Juruplan Scheme is for employers having more than 200 employees and the SMI Training Needs Analysis Consultancy Scheme is for smaller organisations which has less than 199 employees.

In addition, there is the PERLA Scheme (Perjanjian Latihan Dengan Latihan) in which a training agreement with selected registered training providers is needed. This Training Agreement Scheme enables employers to send employees for skills training and upgrading without paying the full amount for training provided. This scheme is almost similar to the SBL Pre-Approved Scheme in which employers can claim for training provided without supporting documents as required by other schemes as the programmes has been evaluated and recognised by SBL Pre-Approved Programme.

In supporting organisations to provide in-house training to its employees, the HRDC provides funds for setting up training rooms and facilities and for the purchase of training equipment necessary for employees training needs. These funds are available through the scheme for purchasing training equipment and facilities.

At the same time, with the strive for workers' knowledge on ICT through the Workers' ICT Scheme (WITS), in which employers are encouraged to provide computer knowledge among workers in an effort to increase the expertise and knowledge on information and communications technology (ICT), support is provided for the purchasing of computers for these efforts. Hence, in line with the Government's call for more ICT knowledge workers, special funds have been 
set up to carry out the Worker's ICT Scheme in which employers are provided with funds to purchase computers and computer-based training softwares through Computer-Based Training Scheme (Software Development) and ICT-Based Training Scheme.

The retrenched workers laid-off from company's shut-down due to economic slow down are also not excluded. These workers are provided with support for training to enhance and equip them with higher skills to increase their opportunities in securing new employment. Similarly, to the unemployed SPM school leavers. These unemployed school leavers are assisted in obtaining skills to enhance their employment opportunities. This scheme is called the Retrenched Workers and Unemployed Training Scheme with the objective of increasing the supply of skilled workers and assist employers to employ workers with higher skills.

On the other level, graduates left without employment are equipped with ICT skills as well as language skills with commercial value such as English language. Under the Graduate Training Scheme (GTS), graduates are trained and their knowledge and skills upgraded and are paid a monthly allowance of RM500 during the programme.

The other schemes provided by the HRDC are Group or Joint-related schemes in which several employers or associations collaborate or work together to provide group training to its employees. All the schemes provided by the HRDC are financially assisted between 75 to 100 percent with some schemes requiring the necessary supporting documents and prior approval, whilst some schemes are very straightforward in the claims process due to the approved status. Financial assistance for overseas training is 50 percent and 75 80 percent financial assistance for the purchase of training equipment, setting-up of training and purchase of Computer-Aided software. The types of training programmes provided under these schemes ranges from technical and craft skills, computer-related skills, retraining and upgrading skills, apprenticeship and industrial automation for workers in the manufacturing industries and services sector.

There are more than 2,000 training providers established in Malaysia to provide consultancy services and training to workers. However, under the above schemes, only registered providers are allowed to participate. Out of the many training providers available in Malaysia, only about 500 are registered providers and only about 20 percent have the Approved Training Programme Status ${ }^{[8]}$.
Training Centres: In terms of training centres, the Government has supported the development of several facilities for training and skills development. As mentioned earlier, the Government has accredited almost two thousand training providers and institutions. For instance, the FMM Institute of Manufacturing (FMM-IM) was incorporated in 1999 as an effort to expand and focus on training functions, particularly in the manufacturing sector. The objective of the institute is to develop the potentials and enhance the skills of every employee at every level in the industry. This is to create a pool of trained manpower in all aspects of industrial skills and management capabilities to face the challenges as the country moves into the status of an industrialised nation. FMM-IM is a registered training provider with HRDC and it ensures that all its programmes comply with the requirements of the Council to be eligible for training grants under HRDF. A large number of the programmes have been awarded the ATP status and also selected to participate in the PERLA scheme.

Another organization providing training facilities to all private sectors is the National Productivity Corporation (NPC) which was established under the Ministry of International Trade and Industry to assume an important role in the enhancement of productivity and quality of the country towards achieving a higher national economic growth. NPC core functions are productivity and quality research, training and management system development, productivity and quality promotion and benchmarking service. Besides providing these services, NPC also provides professional consultancy and training in the areas of productivity and quality.

In addition, there are other institutions established by the Government to provide the facilities for training and skills upgrading. In the SMIs, SMIDEC has appointed 10 skills development institutions to provide technical skills training in the SMIs. And under the Agreement between SMIDEC and the institutions, SMIDEC will finance 50 percent of the training fees undertaken by the SMIs. Other institutions include Industrial Training Institute (ITI) which provides formal technical training for workers in the industrial sector and Centre for Instructor and Advanced Skill Training (CIAST) to provide training for vocational instructors.

The individual organisation is expected to establish its own training centre with the support provided under the setting up of training centre or room and facilities. However, only the larger organizations such as Proton 
and Perodua which is a Government Linked Company (GLC) and multinationals such as Panasonic and Samsung, as well as the hospitality and services industries has its own training centres. Nonetheless, there are some locally owned companies that have its own training centre. And in these training centres, employers can organise their own in-house training programmes for its employees

Other than the individually owned training centres by the organisations, employers can organise training programmes and utilise the centre and facilities provided by private training providers. As mentioned above, there are more than 500 registered training providers under HRDC and also polytechnics that can be utilised under the Time Sector Privatisation (TSP) programme. The TSP programme allows private and public companies to utilise the training facilities available at the polytechnics to upgrade the skills of the workers.

In addition to technical training, the private sector is also supported in terms of providing training in the areas of safety and health. The NVTC supports the manufacturing sector in technical skills training, whilst the National Institute of Occupational Safety and Health (NIOSH) supports in terms of providing consultancy, training, information dissemination and research in the areas of occupational safety and health. NIOSH, established by the Government in December, 1992 is to ensure that organisations in Malaysia operate in a safe and healthy working environment. The Board of Directors of NIOSH comprises of ten members appointed by the Government, while the remaining members are elected members during the Annual General Meeting which makes NIOSH different from similar institutions in other countries ${ }^{[10]}$.

\section{CONCLUSION}

The priority of the government with the plans in place and the objective in mind have given increase accessibility to quality education and training in strengthening the human capital to support the development of k-economy. The transformation of the economy demands for technological skills and expertise as well as labour force equipped with tacit knowledge and a high level of thinking skill. Hence, numerous efforts have been made by the Government to ensure that education and training system has the capacity to enhance the quality of intellectual capital as well as expand human capital.

With the implementation of the broad policies of the country, policies from the Ministry responsible for human resources and HRD and the legislation available to support knowledge and skills development of the workforce is a driving force to support and encourage the employers in the private sector to provide training and development to its workers.

Moreover, the Government has established several bodies to oversee the administration and promotion of HRD activities. For instance, the HRD Council is responsible for the administration of funds contributed by employers for workers' training, and the NVTC is responsible for promoting and development of skills training. However, the NVTC has its own allocation of funds from the country's budget to promote the development of technological and skills training.

The HRD system in Malaysia has different categories of training and education. First, is the formal academic education obtained from the universities, colleges and other similar institutions. Secondly, is the formal training and education from the technical and vocational institutions obtained from polytechnics all over the country. And finally, for working individuals, there are informal training and development obtained from the various programmes offered by the workplace.

Moreover, the various training schemes and HRD Funds, skills development funds available only to all manufacturing and some service industries irrelevant of their sizes and industries, this financial assistance is not an excuse for the companies in not providing the workers with knowledge and skills needed by the industries.

In conclusion, the Government has supported several institutions in providing training facilities for the private sector such as FMM-IM, NPC, ITI and the polytechnics. Employers can utilise the facilities and services offered by these registered and approved HRDC institutions. Other than utilising external training centres, individually owned training centres in supporting employees' training and development are very limited, with the exception for the larger corporations and some smaller organisations. Otherwise, training and development for employees are outsourced to private training providers having facilities for training.

Implications: The role and function of $\mathrm{HRD}$ is increasingly vital at the organizational and national level as well as in the global context. Researching and studying HRD in Malaysia is challenged by the lack of empirical studies in the field of HRD. Hence, in understanding Malaysian national strategies towards HRD, will assist academicians and researchers with literature and further research to add justice to the lack 
of empirical literature in Malaysia as well as in the Asia-Pacific region.

Limitations: The first limitation in this paper is mainly confined to the private sector in Malaysia and it was justified in the selection for this sector, thus, it cannot be generalised to other sector other than the private sector. As this paper was written based on reviewing of Governmental reports and documents, the information obtained are assumed to be reliable and valid to represent and generalised for the private sector except specified in some of the context.

The second limitation is related to the research methods. Again as mentioned above, since this paper is a review of documents, this paper is mainly a review and it aims to examine the HRD strategies, plans, policies, roles and responsibilities for national HRD in Malaysia. The limitation is that findings in this paper might not be exhaustive and rigorous.

\section{REFERENCES}

1. Malaysia, Economic Planning Unit, 2001. Economic Planning Unit Report. Prime Minister's Department. Kuala Lumpur

2. Malaysia, Government, 2001a. The Eighth Malaysia Plan, 2001-2005. National Printing Department. Kuala Lumpur
3. Malaysia, New Straits Times, 2005. Ninth Malaysia Plan thrust on human capital. Retrieved 2006, from http://www.nst.com.my/Current_news/NST/Friday/ National/NST32232492.txt/Article/indexb_html. $\underline{04 / 02 / 2005}$.

4. Malaysia, Government 1991. Second Outline Perspective Plan, 1991-2000. National Printing Department. Kuala Lumpur

5. Malaysia, Ministry of Finance 2001. The Economic Report 1999-2000. Kuala Lumpur

6. Malaysia, Government 2001b. Third Outline Perspective Plan, 2001-2010. National Printing Department. Kuala Lumpur

7. Malaysia, Ministry of Human Resources 2004 Ministry of Human Resources. Retrieved 2004, from

http://www.hrdnet.com.my/ucapanmenteri21_0904bi.html. Kuala Lumpur

8. Malaysia, Ministry of Human Resources 2002 Training Guide Malaysia. ( $5^{\text {th }}$ ed) Kuala Lumpur, Challenger Concept

9. Malaysia, Ministry of Education 2001) Education Guide Malaysia ( $7^{\text {th }}$ ed). Kuala Lumpur. Challenger Concept

10. Malaysia, NIOSH, 2002 National Institute of Occupational Safety and Health Corporate and Training Info. Kuala Lumpur 